\author{
Rafał Michałowski \\ University of Bialystok, Poland \\ ORCID: 0000-0003-3255-4908 \\ r.michalowski@uwb.edu.pl
}

\title{
Regulation of Protection of Agricultural Land and Limitation of Ownership Rights to Real Estate
}

\author{
Regulacja prawna ochrony gruntów rolnych a ograniczenia prawa \\ własności nieruchomości
}

\section{SUMMARY}

Regulations of the Act on Protection of Agricultural and Forest Land are treated as a limitation of the right of ownership of the real estate. Unlike civil law regulations, in this Act the legislator defines agricultural land as the subject of obligations specified in the Act, treating them in separation from the issue of ownership relationships. Unlike in civil law regulations, apart from the owner, a number of obligations associated with the protection of agricultural land is also imposed on other entities, which make economic use of the real estate property. According to the Act, the owner of real estate property has a number of obligations, such as prohibition to use land for non-agricultural purposes without having obtained a decision to designate the land for non-agricultural purposes and consent for exclusion of land from production. The owner also has other positive duties, such as the duty to prevent land degradation and devastation. These obligations, however, do not shape the subjective right of ownership, but are external to it, although they should be treated as a limitation to this right.

Keywords: ownership; agricultural land; limitation of ownership; subjective right; public law; private law 
The essence of legal regulations regarding the protection of agricultural land can be analyzed in various dimensions. On the one hand, legal literature states that the obligation to protect agricultural law is a component of environmental protection. In this interpretation, environmental protection is a public task, which takes into account the protection of agricultural land ${ }^{1}$.

This stance corresponds with provisions of Article 81 (1) of the Act of 27 April 2001 - Environmental $\mathrm{Law}^{2}$, stating that protection of environmental resources is implemented on the basis of the ELA and separate legal provisions. On the other hand, according to Article 81 (4) ELA, the specific rules for the protection of agricultural land are specified by provisions of the Act of 3 February 1995 on Protection of Agricultural and Forest Land ${ }^{3}$.

According to W. Radecki, who refers to the provision of the ELA, quoted above, protection of agricultural law falls within the scope of environmental protection law - within the framework of regulations for the protection of earth surface. Therefore, interpretation of provisions of the APAL should take into account the rules specified in the APAL ${ }^{4}$. The author, however, has also noticed the link between this matter and agricultural law 5 .

On the other hand, in the literature on agricultural law, it has been emphasized that solutions regulating environmental protection and protection of agricultural land are not always aiming in the same direction, and the objective of regulations for the protection of agricultural land is to protect the land as a factor of production ${ }^{6}$.

Regardless of which of the listed aspects should be perceived as being the leading regulation for the protection of agricultural land, it is - according to the popular stance expressed in the civil law doctrine - the source of normative limitations to ownership rights to real estate.

In general, the issue of interference with ownership rights in the context of provisions of the APAL has been discussed by G. Matusik ${ }^{7}$ and M. Orlicki ${ }^{8}$. Moreover, the administrative law aspects of the APAL provisions have been pointed out, some

1 P. Korzeniowski, Cele i funkcje ochrony gruntów rolnych i leśnych, „Prawo i Środowisko” 2012, nr 3, p. 123.

2 Journal of Laws 2019, item 1396 as amended, hereinafter: ELA.

3 Journal of Laws 2017, item 1161, hereinafter: APAL.

4 W. Radecki, Ustawa o ochronie gruntów rolnych i leśnych. Komentarz, Warszawa 2012, p. 42.

5 Ibidem.

6 P. Czechowski, K. Marciniuk, Ochrona gruntów rolnych, [in:] Prawo rolne, red. P. Czechowski, Warszawa 2019, p. 391.

7 G. Matusik, [in:] Kodeks cywilny. Komentarz, t. 2: Własność i inne prawa rzeczowe, red. K. Osajda, Warszawa 2017, p. 10.

8 M. Orlicki, [in:] Kodeks cywilny, t. 1: Komentarz do art. 1-352, red. M. Gutowski, Warszawa 2018, p. 1099. 
of which pertain to the owner's right to use land ${ }^{9}$. In terms of use of the real estate, it is believed that regulations that interfere with the scope of rights of the owner are the provisions based on the APAL on the designation of agricultural and forest land for other purposes ${ }^{10}$. E. Gniewek points to the positive obligations of the owner (facere), based on these provisions. He also points out that such limitations to the right of ownership of the real estate are being gradually eliminated from modern legislation ${ }^{11}$.

The same aspect has been pointed out by E. Skowrońska-Bocian and M. Warciński with reference to the statutory obligation to prevent soil degradation, which is applicable to agricultural farmland and land reclaimed for agricultural purposes ${ }^{12}$.

In the context of the subject of analysis, contained in this article, it is necessary to emphasize the public and legal nature of regulations for the protection of agricultural land, classified as limitations to ownership rights to real estate. Looking at these regulations from the perspective of the civil law structure of ownership of the real estate, it is necessary to take into account the different methods of regulating social relationships in public and private law. This has important implications for characteristics of the regulations contained in the Act on Protection of Agricultural and Forest Land as limitations to the civil law - based right of ownership. Worth analyzing is this very difference in regulations, which constitutes the foundation of interpretation of ownership as a subjective right, belonging to ius privatum, and regulations with regard to the protection of agricultural land, belonging to the sphere of ius publicum.

II.

The Act on Protection of Agricultural Land establishes standards to be interpreted on the basis of its provisions, for which the object is the specifically understood agricultural land, while the object of property as the subjective right can be any real estate property, including an agricultural property, defined in Article $46^{1}$ of the Civil Code ${ }^{13}$. In this definition, the term "agricultural land" has been referred to synonymously ${ }^{14}$. However, the important issue - from the perspective of private

9 K. Zaradkiewicz A. Stelmachowski, [in:] System Prawa Prywatnego, t. 3: Prawo rzeczowe, red. E. Gniewek, Warszawa 2013, p. 320.

${ }_{10}$ W. Szydło, [in:] Kodeks cywilny. Komentarz, red. E. Gniewek, P. Machnikowski, Warszawa 2019, p. 344.

${ }_{11}$ E. Gniewek, [in:] System Prawa Prywatnego..., p. 398.

${ }^{12}$ E. Skowrońska-Bocian, M. Warciński, [in:] Kodeks cywilny. Komentarz, t. 1: Art. 1-449 ${ }^{10}$, red. K. Pietrzykowski, Warszawa 2018, pp. 519-520.

13 Act of 24 April 1964 - Civil Code (Journal of Laws 2019, item 1145), hereinafter: CC.

${ }^{14}$ On doctrinal concerns associated with defining the relationship between the terms "agricultural property" and "agricultural land" within the scope of regulations of the Civil Code, see P. Wojciechowski, [in:] Instytucje prawa rolnego, red. M. Korzycka-Iwanow, Warszawa 2019, p. 173. 
law - is that any agricultural property is always a real estate property; that (like any other real estate property) it is a unit of ownership - delimited by the fact that someone has the right of ownership of a given part of the earth surface.

Article 2 (1) APAL, on the other hand, contains a definition (based on enumeration) of agricultural lands. It has been pointed out that this definition is not consistent not only with the Code-based definition of agricultural property but also with casual understanding of the term "agricultural land", which is identified in this interpretation with the top layer of soil used for cultivation purposes ${ }^{15}$.

The semantic inconsistency of terms contained in the Civil Code and in the Act on Protection of Agricultural Land is not anything unusual, considering the fact that the legislator constructs the meaning of terms, which are used in the text of a given legal act. Therefore, there is no reason not to use in a specific legal act (which is often done in practice) a meaning, which departs from the one adopted in another legal act or from the meaning adopted in general language.

In the literature on the subject, it has been pointed out that the term "agricultural land" within the framework of regulations for protection of agricultural land has always been treated as having priority over ownership ${ }^{16}$. Claims have also been made that "agricultural land" in the legislation aimed at land protection has been presented as having priority over such terms as "agricultural farmland" or "agricultural property"17.

It should be pointed out that referring to the term "agricultural land" having a "priority" over the concept of ownership or over the concept of agricultural property, we mean that the sphere of property relationships in the context of classification of a given part of land as agricultural land defined for the purpose of its protection is, in general, perceived as being of no significance ${ }^{18}$. The characteristics, which comprise the "land" in the sphere of public law regulations, including protection of agricultural land, are mainly its physical properties, while the aspect of ownership has been disregarded ${ }^{19}$. The issue is not about determining whether the scope of the term "agricultural property" is included in the term "agricultural land" - thus, whether we are dealing with more or less general terms.

${ }^{15}$ M. Król, Reglamentacja korzystania z powierzchni ziemi, [in:] Reglamentacja korzystania ze środowiska jako funkcja administracji samorzadowej, red. P. Korzeniowski, I. Wieczorek, Łódź 2018, p. 194.

16 Ibidem.

17 A. Stelmachowski, K. Zaradkiewicz, op. cit., p. 320.

18 Although it cannot be overlooked that the addressee of obligations provided for in the provisions of the APAL is, in many cases, the person, who should be defined as the "owner" in accordance with Article 4 (4) APAL.

19 B. Wierzbowski, Planowanie przestrzenne i ewidencja gruntów i budynków a prawo własności nieruchomości, „Przegląd Prawa Rolnego” 2012, nr 1, p. 34. 
M. Stańko has rightly pointed out that agricultural land constitutes mainly all land referred to in record-keeping regulations as agricultural farmland ${ }^{20}$. It should be pointed out that in some of the provisions of the APAL, which constitute a limitation of ownership rights to real estate, the scope of impact of individual solutions is limited specifically to agricultural farmland (Article 7 (2) (1), Article 15 (1) - apart from agricultural farmland, it also pertains to land reclaimed for the purpose of agricultural activity).

As it has been noted by Z. Truszkiewicz, the concept of agricultural farmland can be associated, but not identified with agricultural property, e.g. due to the fact that a given part of the earth surface entered in the register of lands and buildings as agricultural farmland may (also due to illegal activity) permanently used its characteristics, which allow for its agricultural use. It is also possible for land not being classified as arable farmland to be used for agricultural activity ${ }^{21}$.

Therefore, if we consider legal measures based on the APAL as limitations to ownership rights to real estate, these should be referred to the land property as defined in the Civil Code (units of ownership), which include the land categories specified in Article 2 (1) APAL, first of all, agricultural farmland. Application of provisions based on the APAL thus depends on whether a real estate property encompasses an area of land belonging to any of the categories listed in Article 2 (1) APAL, and the neutral issue in this context is whether a given land property, encompassing the lands listed in Article 2 (1) APAL may, at the same time, be qualified as agricultural property, referred to in Article $46^{1} \mathrm{CC}$, although in many cases this will be true.

III.

On the basis of provisions of the Civil Code, obviously, the owner is the person entitled to the right of ownership of assets, including land real estate. The Act on Protection of Agricultural and Forest Land contains an autonomous regulation of the term "owner". According to Article 4 (4) APAL, the "owner" includes an owner-like possessor, a manager or a user, a perpetual user and a lessee. However, this definition can only be viewed as specification, on entity basis, of persons, who can be subject to at least some of the legal instruments provided for in the APAL. This definition does not in any way influence the way of understanding of the concept of ownership as a subjective right. As it has been mentioned already, the legislator

${ }^{20}$ M. Stańko, [in:] Kodeks cywilny. Komentarz, red. D. Fras, M. Habdas, t. 1, Warszawa 2017, p. 365.

${ }^{21}$ Z. Truszkiewicz, Przeniesienie własności nieruchomości rolnej w świetle ustawy o ksztaltowaniu ustroju rolnego (część I), „Rejent” 2003, nr 9, pp. 61-62. 
is not interested in the status of a given piece of land as the object of ownership as defined by civil law provisions ${ }^{22}$, but the status of land areas defined on the basis of criteria specified in Article 2 (1) APAL, apart from who is their owner according to civil law provisions. The selection of entities treated as the owner, on the other hand, does not seem to be coincidental. As for economic use of agricultural land (mainly agricultural farmland), the decisive role is played by behaviours of entities that have a given land area at their disposal, which can be referred to as "making use of" and "deriving of benefits". Of course, the basic attribute of an owner according to civil law is the ability to make use of an asset (that is, to use them and derive benefits from them). Also, a perpetual user is authorized to make use of and derive benefits from real estate property (as in Article $233 \mathrm{CC}$ ). The right to make use of and derive benefits is included in the scope of essential provisions of the lease agreement (as in Article $693 \S 1$ CC). In the case of administration, referred to in Article 4 (4) APAL, we are not dealing with a subjective right, because, as it is known, administration (permanent administration) is a form of beneficial ownership of a real estate by organizational unit having no legal personality. In relation to administration, in the APAL, the legislator points to the addressee of standards being the control instruments the organizational unit of the State Treasury or local government units. As for the owner-like possessor, of course, it is not possible to use the categories of subjective rights and thus refer to a civil law based right to use and derive benefits from the land; however, it cannot be overlooked that inclusion of this category of persons in the term "owner" and thus including them in the scope of application and standardization of standards derived from provisions of the APAL is based on the fact that an owner-like possessor is a person, who exerts real influence on the use of land with regard to the concept of "use and deriving of benefits". Moreover, being an owner-like possessor for a sufficient period leads to the acquisition of ownership by the possessor. The above analysis makes it justifiable to conclude that the legislator intentionally included - where individual standards based on the APAL pertain to the owner category - entities, which, in the first place, have the right to use land and derive benefits from it, or at least the actual activity falling within the scope of meaning of the term "use and deriving of benefits" (as an owner-like possessor) that they perform or are able to perform - taking into account the factual relationships.

However, it should be pointed out that not always use in a specific provision of the APAL of the term "owner" necessarily has to mean that in this specific case the aim is to define the rights or obligations of all categories of persons indicated in Article 4 (4) APAL. Considering the subjective scope of the standard derived from Article 17 (1) APAL, concerning claims of the entity referred to as "the owner", it

${ }^{22}$ B. Wierzbowski, Pojęcie nieruchomości rolnej w prawie polskim, „Studia Iuridica Agraria” 2004, t. 4, p. 100. 
is possible to raise a justified concern on whether it really applies to all categories of persons listed in Article 4 (4) of the Act. According to Article 17 (1) APAL, if the owner of land referred to in Article 16 (1) has suffered damage due to reduction of the level of agricultural or forest production, they are entitled to compensation in this regard from the industrial plant. In the case of reduction of the level of production in the period of three years by at least one-third of the former value, the plant is obliged, on demand of the owner, to buy out the part of such land or the entire land at a market price. It would be difficult to assume that the claim for buyout of land might also apply to a lessee or user of the real estate. It can undoubtedly be exercised by the owner as defined in Article $140 \mathrm{CC}$ or a perpetual user of agricultural land. However, it would be necessary to take a different approach in the case of a claim based on the next paragraph of this article, which states that if, as a result of implementation of the plan, referred to in Article 16 (1), it becomes necessary to change the direction of agricultural or forest production, the industrial plant is obliged to reimburse to the land owner the expenditures and costs incurred and pay the equivalent of damages resulting from the change in the direction of production. In this case, there are no reasons to believe that, e.g., a lessee of agricultural land cannot make the claims listed against the industrial plant.

Individual regulations contained in the Act (apart from assessing whether these should be interpreted as limitations to ownership of real estate) may, however, pertain to a broader catalogue of entities than those referred to as the owner for the needs of the act. In particular, it is necessary to point to Article 20, establishing the obligation to reclaim land of any person, who causes loss or reduction of its usable value, which is an intentional act of the legislator, aimed at separating the obligation to reclaim land from the formal owner status as defined in the APAL, imposing this obligation first of all on the actual perpetrator, who caused degradation or devastation of land.

The scope of analysis, being the subject of this publication, does not include a detailed examination of individual legal solutions, which could be qualified as limitations to the ownership right in the APAL, therefore they will be presented here synthetically, to the extent necessary.

Undoubtedly, a limitation in the use of real estate is imposed by the regulation on designation of agricultural land for non-agricultural purposes and exclusion of agricultural land from agricultural production. Non-agricultural use of agricultural land is acceptable, in general, after a given area of land has been designated in the spatial local development plan for purposes other than agricultural activity an upon the issue of the decision allowing for exclusion of land from agricultural activity (see, in particular, Articles 6, 7 and 11 APAL).

Standards, which are significant from the perspective of the use of agricultural land, are based on provisions of Article 15 APAL. This provision regulates, among other things, the obligations of owners associated with counteracting land degrada- 
tion $^{23}$. According to Article 15 (1) APAL the owner of land constituting agricultural farmland and land reclaimed for agricultural purposes is obliged to counteract soil degradation, including, in particular, erosion and mass ground movements. Another obligation imposed upon land owners ex lege is based on Article 15 (4), which specifies the obligation to maintain technical order of anti-erosion equipment and specific drainage equipment. The provisions of Section 2 and 5 Article 15 specify the basis for issue by competent authorities of administrative decisions specifying the obligations of land owners. According to Article 15 (2), a starost, for the purpose of protection of soil against erosion and mass ground movements, may issue a decision to impose upon the land owner, referred to in Section 1, the obligation to plant a forest, trees or bushes or to establish permanent grasslands. On the other hand, Article 15 (5) APAL states that if other forms of soil degradation are caused by the owner, referred to in Section 1, including degradation caused by a failure to comply with provisions on the protection of crops against diseases, pests and weeds, the commune administrator, through a decision, orders the land owner to perform appropriate treatment tasks within the specified time limits.

Separate limitations are imposed by provisions of Article 16 APAL, which does not establish directly the obligations of owners of arable lands, but is the source of competences for resolutions to be passed by the commune council appropriate for the land location to approve the spatial development plans establishing areas of limited use. These plans specify, among other things, the plants that can be cultivated, the cultivation recommendations, as well as the proposed manner of their economic use, the mode of counteracting reduction in usable value of land, and the potential obligations associated with animal production (cf. Article 16 (2) APAL). If production is conducted in the manner that violates the plan, referred to in Article 16 (2) (4) and (9) APAL, the commune administrator, acting in consultation with the state provincial sanitary inspector, orders the land owner within a specific time limit to destroy specific crops, relocate animals outside the area of limited use or to slaughter the animals.

Some concerns may arise due to the attempt to qualify the obligations with regard to land reclaiming as a limitation of the right of ownership of the real estate. The obligation to reclaim land at their own expense, imposed upon the person, who causes reduction of usable value of land (Article 20 (1) APAL), may be viewed not as a consequence of violation of the general prohibition to cause land degradation or devastation, but simply as an obligation, which becomes valid only in the case of occurrence of the condition, referred to as land degradation or devastation. Its

${ }^{23}$ See J. Bieluk, D. Łobos-Kotowska, Ustawa o ochronie gruntów rolnych i leśnych. Komentarz, Warszawa 2015, p. 123. 
emergence is not dependent upon such conditions as fault (cf. Article 15 (5) APAL) - it is sufficient to state that the effect referred to in Article 20 (1) has been caused ${ }^{24}$.

Executing Article 20 (1) APAL, the starost issues the decision on land reclaiming (see Article 22 APAL). In the judicial practice of the Supreme Administrative Court and the voivodeship administrative courts, there is a tendency to treat this regulation as the source of public subjective right ascribed to the real estate owner. As it has been stated by the Supreme Administrative Court in its judgement of 5 July 2016:

$[\ldots]$ the unconditional obligation to reclaim land is not an individual right of the owner of land, but a subjective right of public nature, based on Article 74 of the Constitution of the Republic of Poland. Therefore, issuing decisions on reclaiming of land, the administrative bodies, first of all, protect the public interest, which lies at the foundation of statutory protection of agricultural and forest land as a public good. Execution of this obligation must not be prevented by civil law provisions on the protection of property. Decisions issued on the basis of Article 22 (1) do not limit the right of ownership, but, in fact, serve its protection by obliging the "perpetrator" of land devastation or degradation to reclaim it (Article 20 (1) of the Act quoted) ${ }^{25}$.

The regulation on the obligation to reclaim land indeed has specific characteristics (association with the actual perpetrator of the violation), which undermine obviousness of perceiving them as a limitation to the right of ownership of the real estate $^{26}$, however, its perception as the source of public subjective right of the land owner does not seem to be unquestionable either - if we were to characterize the positive aspects of the owner's position due to regulations contained in Article $20 \mathrm{ff}$. APAL, we could rather search for positive, reflexive effects of this regulation, and not necessarily refer to the public subjective right.

IV.

The ownership right includes - according to Article $140 \mathrm{CC}$ - the right to use assets and the right to dispose of assets. The right to use assets, on the other hand, includes the right to use the asset, to derive benefits from it, to actual disposal, the right to possess assets.

${ }^{24}$ On the unconditional nature of the obligation to reclaim land, see ibidem, pp. 146-147.

25 Judgement of the Supreme Administrative Court of 5 July 2016, I OSK 513/15. The view expressed in this judgement has its source in findings made in the judgement of the Supreme Administrative Court of 2 April 2007, II OSK 1018/06.

${ }^{26}$ In literature, there are references to the statement supported in the judgements of the Supreme Administrative Court, quoted above, that decisions on land reclaiming only prima facie seem to be limitations to the rights of ownership of real estate, while in reality they ensure protection of this right. See M. Woźniak, Ochrona interesu publicznego wobec interesu indywidualnego na gruntach rolnych i leśnych-zagadnienia wybrane, „Człowiek i Środowisko” 2018, nr 1, p. 47. 
The literature rightly classifies the right to use an asset as freedom subject to legal protection ${ }^{27}$. This conclusion is rooted in the part of Article $140 \mathrm{CC}$, which states that "the owner may, with the exclusion of other persons, use the asset", as well as in Article $222 \mathrm{CC}$, which is the source of claims of the owner in the case of violation of their rights ${ }^{28}$. The legal provisions quoted above serve as a source of the standard prohibiting interference of other entities with the use of the assets by its owners. The freedom to use assets by their owner is complemented by the competence to dispose of assets ${ }^{29}$.

The owner is authorized to exercise behaviours, which are within the boundaries defined by the term "use". These - as it has been mentioned - include "making use of", "deriving benefits". In a situation, in which a third person violates the sphere of exclusivity of behaviours of the owner, on the part of the owner, protective instruments are activated, which take the form of a debt collection claim (in the case of loss of possession of an asset) or a restitution claim (in the case of other violations of ownership, which do not result in loss of possession of an asset). However, this civil law legal structure of ownership, based on Article $140 \mathrm{CC}$ and Article 222 $\mathrm{CC}$ is not shaped by the provisions of the APAL. Therefore, if, for instance, the owner used agricultural land for any purpose other than agricultural activity, e.g. contrary to the requirements of the APAL with regard to obtaining of the consent for exclusion of land from agricultural production ${ }^{30}$, such circumstance does not authorize a third person to interfere with the sphere of free use by the owner of their real estate property to the extent, in which land use is inconsistent with the regulations of the APAL. Should the owner be deprived of possession of the land they would be entitled to a debt collection claim, and in the case of other violations - to a restitution claim. The owner of real estate has the freedom, within the spatial boundaries of the real estate property specified on the basis of Article $143 \mathrm{CC}$, to exercise behaviours, which fall within the scope of freedom of using assets. As for behaviours of the owner included in the scope of the term "use", referred to in Article $140 \mathrm{CC}$, the scope of this freedom is not directly determined by all regulations of public and private law, applicable to a given entity as the owner of the real estate property. This pertains to legal regulations that establish relationships between civil law entities - the owner and persons subject to the obligation to abstain from interfering with the sphere of freedom of the owner. Interference with the sphere

${ }^{27}$ S. Wronkowska, [in:] S. Wronkowska, Z. Ziembiński, Teoria prawa, Poznań 2001, pp. 103-104.

${ }^{28}$ P. Machnikowski, [in:] System Prawa Prywatnego ..., p. 13.

${ }^{29}$ Ibidem.

30 These remarks should also be applied to use of land in the manner, which is inconsistent with the spatial development plan in an area of limited use surrounding an industrial plant, however, taking into account the fact that in such situation, we are not dealing directly with violation of a statutory obligation. 
of exercise of possession by the owner by another civil law entity is justified, if it is based on subjective rights of the person committing such interference, or on the legal provisions allowing for such interference. On the other hand, provisions of the APAL do not establish legal relationships between the owner and third persons, which would legitimize third persons to interfere with possession of the real estate property by the owner. Therefore, this regulation cannot be perceived as definingdirectly and in accordance with Article $140 \mathrm{CC}$ - the scope of rights of the owner in terms of use of the real estate property.

This, however, does not mean that we are not dealing with the limitation of ownership of the real estate. The public regulations under concern do not provide entities other than the owner with any rights that would legitimize their interference with the sphere of rights of the real estate owner; however, as a result of their application, the owner's freedom to exercise tasks that fall within the scope of "use" of real estate property is limited - although the mechanism of enforcement of the prohibition to undertake such activity does not belong to the scope of civil law, but it does belong to the sphere of ius publicum.

The above remarks should be complemented with analysis of the nature of active obligations of the agricultural land owner. As it has been mentioned, accordingly with Article 15 (1) APAL, the owner of land constituting agricultural farmland and land reclaimed for agricultural purposes is obliged to counteract land degradation, in particular, erosion and mass ground movements. Within the scope of obligations of the land owner, the potential positive effects of exercising of the decision referred to in Article 15 (5) for third parties, including owners of other real estate property, can be considered to be a reflective impact, as the objective of the decision is solely to fix a situation, in which land degradation takes place.

A failure to perform the public law obligation referred to in Article 15 (1) APAL does not result in emergence of any claims of third parties against the owner of the real estate property, including land subject to the obligation based on this provision $^{31}$. In fact, analysis of court and administrative decisions justifies the conclusion that owners of neighbouring real estate properties, dissatisfied with the mode of use of land by their neighbour, may submit a request for initiation of the proceedings referred to in Article 15 (5) APAL. However, owners of neighbouring properties do not have the status that would allow them to claim initiation of the proceedings and issue of a specific decision. The basis for proving legal interest of third parties is not provided, in particular, by provisions of the APAL, which do not authorize owners of other real estate properties (including the neighbouring properties) to recognize them as the parties to proceedings regulated by these

${ }^{31}$ In the case of a failure to perform the obligation imposed upon the decision referred to in Article 15 (5) APAL, in accordance with this provision, the commune administrator orders substitute performance of these activities at the cost of the land owner. 
provisions, and thus do not authorize them to claim initiation of such proceedings. Therefore, any requests submitted by them in this regard can be only considered to constitute a notification ${ }^{32}$.

It cannot be ruled out that a specific behaviour of the owner, at the same time violating the obligation specified in Article 15 (1) APAL, will violate the civil law - based rights of another entity, such as an owner of a neighbouring property, constituting e.g. prohibited nuisance, referred to in Article 144 CC. Under such circumstances, the owner of the neighbouring property may make claims in association with prohibited impact being exerted on their property. However, even in such case, the claim may arise, if the conditions specified in provisions of civil law have been met.

The above analysis justifies the view that provisions of the APAL constitute a limitation to the right of ownership of land, in particular - agricultural land, with regard to rights of the owner pertaining to the sphere of use of the asset. However, these limitations should not be interpreted in terms of the civil law - based right of ownership, but as a factor, which is, in fact, "external" to the ownership right. As for the positive obligations based on provisions of the APAL, they should be perceived as a specific correlate of the right of ownership ${ }^{33}$.

\section{REFERENCES}

\section{Literature}

Bieluk J., Łobos-Kotowska D., Ustawa o ochronie gruntów rolnych i leśnych. Komentarz, Warszawa 2015.

Czechowski P., Marciniuk K., Ochrona gruntów rolnych, [in:] Prawo rolne, red. P. Czechowski, Warszawa 2019.

Gniewek E., [in:] System Prawa Prywatnego, t. 3: Prawo rzeczowe, red. E. Gniewek, Warszawa 2013. Habdas M., [in:] Kodeks cywilny. Komentarz, t. 2: Własność i inne prawa rzeczowe, red. M. Habdas, D. Fras, Warszawa 2017.

Korzeniowski P., Cele i funkcje ochrony gruntów rolnych i leśnych, „Prawo i Środowisko” 2012, nr 3. Król M., Reglamentacja korzystania z powierzchni ziemi, [in:] Reglamentacja korzystania ze środowiska jako funkcja administracji samorzadowej, red. P. Korzeniowski, I. Wieczorek, Łódź 2018.

Machnikowski P., [in:] System Prawa Prywatnego, t. 3: Prawo rzeczowe, red. E. Gniewek, Warszawa 2013.

Matusik G., [in:] Kodeks cywilny. Komentarz, t. 2: Własność i inne prawa rzeczowe, red. K. Osajda, Warszawa 2017.

Orlicki M., [in:] Kodeks cywilny, t. 1: Komentarz do art. 1-352, red. M. Gutowski, Warszawa 2018.

32 Judgement of the Voivodeship Administrative Court in Rzeszów of 4 October 2017, II SA/ Rz 729/17.

33 This expression is used by M. Habdas, [in:] Kodeks cywilny. Komentarz, t. 2: Własność i inne prawa rzeczowe, red. M. Habdas, D. Fras, Warszawa 2017, p. 30. 
Radecki W., Ustawa o ochronie gruntów rolnych i leśnych. Komentarz, Warszawa 2012.

Skowrońska-Bocian E., Warciński M., [in:] Kodeks cywilny. Komentarz, t. 1: Art. 1-449 ${ }^{10}$, red. K. Pietrzykowski, Warszawa 2018.

Stańko M., [in:] Kodeks cywilny. Komentarz, red. D. Fras, M. Habdas, t. 1, Warszawa 2017.

Stelmachowski A., Zaradkiewicz K., [in:] System Prawa Prywatnego, t. 3: Prawo rzeczowe, red. E. Gniewek, Warszawa 2013.

Szydło W., [in:] Kodeks cywilny. Komentarz, red. E. Gniewek, P. Machnikowski, Warszawa 2019.

Truszkiewicz Z., Przeniesienie własności nieruchomości rolnej w świetle ustawy o ksztaltowaniu ustroju rolnego (część I), „Rejent” 2003, nr 9.

Wierzbowski B., Planowanie przestrzenne i ewidencja gruntów i budynków a prawo własności nieruchomości, „Przegląd Prawa Rolnego” 2012, nr 1.

Wierzbowski B., Pojęcie nieruchomości rolnej w prawie polskim, „Studia Iuridica Agraria” 2004, t. 4.

Wojciechowski P., [in:] Instytucje prawa rolnego, red. M. Korzycka-Iwanow, Warszawa 2019.

Woźniak M., Ochrona interesu publicznego wobec interesu indywidualnego na gruntach rolnych i leśnych-zagadnienia wybrane, „Człowiek i Środowisko” 2018, nr 1.

Wronkowska S., [in:] S. Wronkowska, Z. Ziembiński, Teoria prawa, Poznań 2001.

\section{Legal acts}

Act of 24 April 1964 - Civil Code (Journal of Laws 2019, item 1145).

Act of 3 February 1995 on Protection of Agricultural and Forest Land (Journal of Laws 2017, item 1161).

Act of 27 April 2001 - Environmental Law (Journal of Laws 2019, item 1396 as amended).

\section{Case law}

Judgement of the Supreme Administrative Court of 2 April 2007, II OSK 1018/06.

Judgement of the Supreme Administrative Court of 5 July 2016, I OSK 513/15.

Judgement of the Voivodeship Administrative Court in Rzeszów of 4 October 2017, II SA/Rz 729/17.

\section{STRESZCZENIE}

Uregulowania ustawy o ochronie gruntów rolnych i leśnych są traktowane jako ograniczenia prawa własności nieruchomości. Odmiennie niż w regulacji cywilnoprawnej prawodawca przedmiotem obowiązków określonych w tej ustawie czyni grunty rolne, których ujęcie abstrahuje od problematyki stosunków własnościowych. W przeciwieństwie do przepisów prawa cywilnego, oprócz właściciela, szereg obowiązków związanych z ochroną gruntów rolnych został nałożony także na inne podmioty, które wykorzystują nieruchomości w sposób ekonomiczny. Właściciel nieruchomości ma zgodnie z regulacją ustawy szereg obowiązków, takich jak zakaz jej nierolniczego wykorzystania bez uprzedniego przeznaczenia terenu na cele nierolnicze oraz bez uzyskania zgody na wyłączenie gruntów z produkcji. Obciążają go również czynne obowiązki, m.in. obowiązek przeciwdziałania degradacji gruntów. Powinności te nie kształtują podmiotowego prawa własności, ale pozostają wobec niego zewnętrzne, jakkolwiek powinny być traktowane jako jego ograniczenia.

Słowa kluczowe: własność; grunty rolne; ograniczenie własności; prawo podmiotowe; prawo publiczne; prawo prywatne 